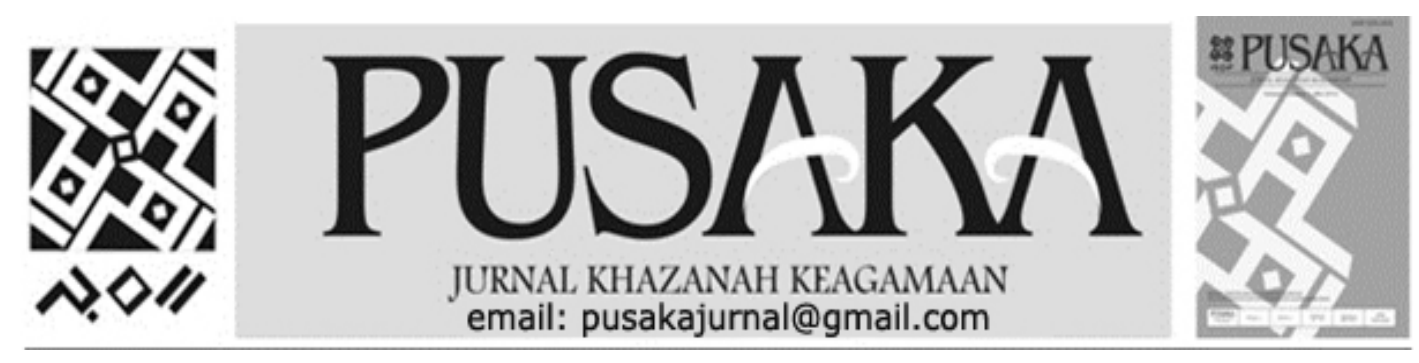

\title{
Pengembangan Madrasah Aliyah Swasta Kabupaten Kolaka
}

\section{Development of Private Madrasah Aliyah in Kolaka District}

\author{
Abdul Rahman Arsyad \\ Balai Penelitian dan Pengembangan Agama Makassar \\ Jl.A.P.Pettarani No.72 Makassar. Telp:0411-452952 \\ Email: arsyadrahman056@gmail.com
}

\begin{tabular}{|c|c|}
\hline $\begin{array}{c}\text { Info } \\
\text { Artikel }\end{array}$ & Abstract \\
\hline $\begin{array}{c}\text { Diterima } \\
27 \\
\text { Januari } \\
2017 \\
\text { Revisi I } \\
16 \\
\text { Maret } \\
2017\end{array}$ & $\begin{array}{l}\text { Penelitian ini menelusuri pengembangan madrasah aliyah swasta di Kabupaten } \\
\text { Kolaka dengan melihat tingkat capaian standar nasional pendidikan (SNP) pada } \\
\text { delapan komponen. Penelitian ini menggunakan metode kuantitatif, adapun teknik } \\
\text { pengumpulan data yaitu: angket, wawancara, observasi dan dokumentasi. Tingkat } \\
\text { capaian madrasah aliyah bervariatif dalam mengembangkan madrasah, terutama } \\
\text { pada aspek ciri khas (penambahan materi agama yang relevan dengan mata } \\
\text { pelajaran umum dan fasilitas kegiatan ekstrakurikuler), tenaga pendidik dan } \\
\text { kependidikan (pengembangan SDM, perekrutan, penempatan), serta sarana dan } \\
\text { prasarana (ruang, fasilitas dan media pembelajaran). Manajemen pengelolaan } \\
\text { madrasah, sepenuhnya merujuk pada kebijakan yayasan. Sehingga inovasi dan } \\
\text { kreatifitas pengelola kurang menguat dalam mengembangkan madrasah, terutama } \\
\text { membangun kerjasama pada semua elemen dalam pemenuhan operasional } \\
\text { pembelajaran. } \\
\text { Kata kunci: Kualitas, Madrasah Aliyah, Pengembangan, Kolaka }\end{array}$ \\
\hline $\begin{array}{c}\text { Revisi II } \\
5 \\
\text { April } \\
2017 \\
\text { Disetujui } \\
18 \\
\text { April } \\
2017\end{array}$ & $\begin{array}{l}\text { This research traces the development of private madrasah in Kolaka district by } \\
\text { looking at the achievement level of national education standard (SNP) on eight } \\
\text { components. This study uses quantitative methods, as for data collection } \\
\text { techniques namely: questionnaires, interviews, observation and documentation. } \\
\text { The level of achievement of madrasah aliyah is varied in the development of } \\
\text { madrasah, especially on the characteristic aspects (the addition of religious } \\
\text { material relevant to general subjects and facilities of extracurricular activities), } \\
\text { educators and education (human resource development, recruitment, placement), } \\
\text { and facilities and infrastructure (space, facilities and learning media. } \\
\text { Management of madrasah management, fully refers to the policy of the foundation. } \\
\text { So that the innovation and creativity of managers are less strong in developing } \\
\text { madrasah, especially build cooperation on all elements in the fulfillment of } \\
\text { operational learning. } \\
\text { Keywords: Quality, Madrasah Aliyah, Development, Kolaka }\end{array}$ \\
\hline
\end{tabular}




\section{PENDAHULUAN}

Pemahaman dan pengetahuan masyarakat dulu tentang lembaga pendidikan madrasah sangat bervariatif. Terkadang madrasah dijadikan sebagai pilihan kedua setelah sekolah umum, begitupun halnya dengan prestasi dan keunggulan yang selalu dijadikan sebagai barometer untuk menyekolahkan anak. Pada dasarnya masyarakat belum memahami kalau madrasah sekarang telah mengalami pergeseran atau perubahan terutama pada aspek proses pembelajaran, mutu sarana dan prasarana, maupun pada kompetensi atau kualitas lulusan.

Lembaga pendidikan agama (madrasah) sebagai sekolah umum yang berciri khas Islam pada hakekatnya memiliki keunggulan dengan satuan pendidikan lainnya (SMA/SMK) hal ini dikarenakan madrasah mampu memadukan antara pendidikan umum dan keagamaan. Keunggulan ini perlu diekspos dan dibuktikan pada masyarakat bahwa madrasah aliyah swasta bisa, sehingga animo masyarakat memasukkan anaknya di madrasah semakin tinggi.

Dalam rangka mencapai tujuan bidang agama dan pendidikan yang menjadi tugas Kementerian Agama, maka Kementerian Agama telah menetapkan sasaran strategi, yaitu sebagai berikut: Pertama; Sasaran peningkatan kualitas penyelenggaraan pendidikan pada semua jenjang pendidikan dalam meningkatkan kualitas pelayanan pendidikan, diantaranya: Akreditasi Madrasah; b) Prodi PTK; c) Standar Nasional Pendidikan (SNP) Madrasah. Kedua; sasaran terkait peningkatan kualitas pendidik dan tenaga kependidikan yang memiliki kompoten, profesional, dan bersertifikat.

Balai penelitian Dan Pengembangan Agama Makassar telah melakukan penelitian Kualitas Madrasah sejak 2013 - 2016, yang dilaksanakan di berbagai propinsi (Gorontalo, Sulbar, Kaltim, dan Sulsel), dimana memiliki tingkat kualitas yang bervariatif, walaupun sebagian besar telah terakreditasi. Namun, dari aspek sarpras memiliki tingkat kualitas yang rendah.

Penelitian pengembangan madrasah, bertujuan untuk mengetahui tingkat kualitas MAS dengan melihat berbagai aspek, diantaranya: Kurikulum, proses pembelajaran, Lulusan, pendidik dan Tenaga Kependidikan, Sarpras, pengelolaan, Pembiayaan, Penilaian Madrasah dan Ciri Khas Madrasah, serta memetakan kualitas madrasah berdasarkan SNP. Adapun masalah penelitian, yaitu: Bagaimana Tingkat Ketercapaian Kualitas MAS di kabupaten Kolaka.

Pemetaan kualitas pendidikan agama dan keagamaan urgen untuk dilakukan di kabupaten Kolaka untuk memberikan informasi kepada pemerintah dalam menyusun dan menetapkan kebijakan.

Berdasarkan latar belakang di atas, maka masalah penelitian adalah Bagaimana Tingkat Capaian Standar Nasional Pendidikan (SNP) Madrasah Aliyah Swasta Kabupaten Kolaka?

Penelitian ini bertujuan untuk mengetahui sejauh mana ketercapaian Madrasah Aliyah berdasakan Standar Nasional Pendidikan (SNP). Adapun 
kegunaannya adalah: a) Secara Praktis; Merupakan bahan pertimbangan Kementerian Agama dalam merancang dan menetapkan kebijakan dalam peningkatan kualitas pada komponen satuan pendidikan agama dan keagamaan di Kabupaten Kolaka, b) Secara Teoritis; Dapat menghasilkan konsep atau fenomena ilmu pendidikan agama

\section{Tinjauan Pustaka}

Pendidikan nasional yang berdasarkan Pancasila dan UndangUndang Dasar Negara Republik Indonesia Tahun 1945 berfungsi mengembangkan kemampuan dan membentuk watak serta peradaban bangsa yang bermartabat dalam rangka mencerdaskan kehidupan bangsa, bertujuan untuk mengembangkan potensi peserta didik agar menjadi manusia yang beriman dan bertaqwa kepada Tuhan Yang Maha Esa, berakhlak mulia, sehat berilmu, cakap, kreatif, mandiri, dan menjadi warga negara yang demokratis serta bertanggung jawab.

Arti dasar dari kata kualitas dalam Kamus Modern Bahasa Indonesia adalah "kualitet": "mutu"; baik buruknya barang". (Dahlan AlBarry, 1994:329), seperti halnya kualitas diartikan sebagai tingkat baik buruk sesuatu atu mutu sesuatu. (Quraish Shihab, 1999:280).

Sedangkan kalau diperhatikan secara etimologi, mutu atau kualitas diartikan dengan kenaikan tingkat menuju suatu perbaikan atau kemapanan. Sebab kualitas mengandung makna bobot atau tinggi rendahnya sesuatu. Jadi dalam hal ini kualitas pendidikan adalah pelaksanaan pendidikan di suatu lembaga, sampai dimana pendidikan di lembaga tersebut telah mencapai keberhasilan. (Supriyanto, 1997: 225).

Implementasi Undang-Undang Nomor 20 tahun 2003 tentang Sistem Pendidikan Nasional dijabarkan kedalam Peraturan pemerintah Nomor 19 tahun 2005 tentang Standar Nasional Pendidikan. Arahan aturan ini tentang perlunya dilaksanakan delapan standar nasional pendidikan (SNP). Salah satu standar yang harus dikembangkan adalah standar isi. Dokumen standar isi berdasarkan lampiran Peraturan Menteri Pendidikan Nasional Nomor 22 Tahun 2006 Tanggal 23 Mei 2006, yang mencakup : a) Kerangka dasar dan struktur kurikulum yang merupakan pedoman dalam penyusunan kurikulum pada tingkat satuan pendidikan; b) Beban belajar bagi peserta didik pada satuan pendidikan dasar dan menengah; c) Kurikulum tingkat satuan pendidikan yang akan dikembangkan oleh satuan pendidikan berdasarkan panduan penyusunan kurikulum sebagai bagian tidak terpisahkan dari standar isi; dan d) Kalender pendidikan pada satuan pendidikan.

Standar proses adalah standar nasional pendidikan yang berkaitan dengan pelaksanaan pembelajaran pada satuan pendidikan untuk mencapai kompetensi lulusan, yang berisi kriteria minimal proses pembelajaran pada satuan pendidikan dasar dan menengah pada jalur formal, baik sistem paket maupun sistem kredit semester. Lampiran Peraturan Menteri Pendidikan Nasional Nomor 41 Tahun 2007 
Tanggal 23 November 2007 tentang Standar Proses untuk satuan pendidikan Dasar dan Menengah, meliputi perencanaan, pelaksanaan proses pembelajaran, penilaian hasil pembelajaran dan pengawasan pembelajaran yang terlaksana secara efektif dan efesien.

Pendidikan sesungguhnya merupakan sistem yang dibentuk untuk mencapai tujuan tertentu. Sistem adalah "seperangkat komponen yang saling berinteraksi untuk mencapai tujuan tertentu". Proses suatu sistem dimulai dari input kemudian diproses dengan berbagai aktivitas dengan menggunakan teknik dan prosedur, dan selanjutnya menghasilkat output, yang akan dipakai oleh masyarakat lingkungannya. (Syafaruddin dan Irwan Nasution, 2005: 41-43).

Standar Kompetensi Lulusan satuan Pendidikan (SKL-SP) berdasarkan Peraturan Menteri Pendidikan Nasional Nomor 23 Tahun 2006 Tanggal 23 Mei 2006, Standar Lulusan meliputi: 1) SD / MI / SDLB / Paket A; 2) SMP / MTs / SMPLB / Paket B; 3) SMA / MA / SMALB / Paket C; 4) SMK / MAK; bertujuan meletakkan dasar kecerdasan, pengetahuan, kepribadian, akhlak mulia, serta keterampilan untuk hidup mandiri dan mengikuti pendidikan lebih lanjut sesuai dengan kejuruannya.

Sebuah pendidikan dikatakan bermutu jika mampu menghasilkan lulusan yang memenuhi empat kompetensi, yaitu: akademik, profesional, nilai dan sikap, dan kompetensi untuk menghadapi perubahan. (Trianto dan Titik Triwulan Tutik, 2006: 3).
Standar Kompetensi Tenaga Pendidik dan Kependidikan, yang diatur dalam Peraturan Menteri Pendidikan Nasional Nomor 16 tahun 2007 Tanggal 4 Mei 2007 tentang Kualifikasi Akademik dan Kompetensi Guru, Konselor yang diatur dalam Peraturan Menteri Pendidikan Nasional Nomor 27 Tahun 2008. Kompetensi Kepala sekolah/madrasah diatur dalam Peraturan Menteri Pendidikan Nasional Nomor 13 Tahun 2007 Tanggal 17 April 2007 tentang Standar Kepala Sekolah/Madrasah, dan kompetensi pengawas diatur dalam Peraturan Menteri Nasional Nomor 12 Tahun 2007 tentang Standar Pengawas Sekolah/ Madrasah.

Pengertian pendidik adalah pendidik yang menjadi tokoh, panutan, dan identifikasi bagi para peserta didik dan lingkungannya. Oleh karena itu pendidik harus memiliki standar kualitas pribadi tertentu yang mencakup tanggungjawab wibawa, mandiri dan disiplin. (Mulyasa, 2005:37).

Menurut Undang-Undang RI Nomor 14 Tahun 2005 pasal 1 (1) yang dimaksud "Guru yaitu pendidik yang profesional dengan tugas utama mendidik, mengajar, membimbing, mengarahkan, melatih, menilai dan mengevaluasi peserta didik pada pendidikan usia dini jalur pendidikan formal, dasar dan menengah.

Standar Sarana dan Prasarana Satuan Pendidikan dikembangkan berdasarkan SD/MI, SMP/MTs, dan SMA/MA, berdasarkan Peraturan Menteri Pendidikan Nasional Nomor 24 Tahun 2007 Tanggal 28 Juni 2007, yang meliputi: Satuan Pendidikan, Lahan, bangunan 
Gedung, kelengkapan Prasarana dan Sarana.

Pengadaan sarana dan prasarana sekolah biasanya dilakukan untuk memenuhi kebutuhan sesuai dengan perkembangan program sekolah, mengganti barang-barang yang rusak, hilang, dihapuskan atau sebab lain yang dapat dipertanggung jawabkan. Untuk proses pengadaan sarana pendidikan, ada beberapa kemungkinan yang bisa ditempuh, yaitu (1) pembelian dengan biaya pemerintah, (2) pembelian dengan biaya dari SPP, (3) atau bantuan dari masyarakat lainnya. (Hasbullah, 2007: 120).

Perlengkapan atau sarana pendidikan adalah semua barang yang diperlukan baik yang bergerak maupun yang tidak bergerak sebagai sarana penunjang pelaksanaan tugas di sekolah. (Piet A. Sahertian, 1994:170)

Prasana pendidikan adalah semua perangkat kelengkapan dasar yang secara tidak langsung menunjang pelaksanaan disekolah. Penekanan pada pengertian tersebut ialah pada sifatnya, sarana bersifat langsung, dan prasarana tidak bersifat langsung dalam menunjang proses pendidikan. (Barnawi \& M. Arifin, 2012: 48).

Standar

Pengelolaan

Pendidikan, merujuk pada Peraturan Menteri Pendidikan Nasional Nomor 19 Tahun 2007 Tanggal 23 Mei 2007 tentang Standar Pengelolaan yang meliputi: Perencanaan Program, Pelaksanaan Rencana Kerja, Pengawasan dan Evaluasi, Kepemimpinan Kepala Sekolah/ Madrasah, Sistem Informasi Manajemen, dan Penilaian Khusus.
Manajemen sering diartikan sebagai ilmu, kiat dan profesi. Dikatakan ilmu karena manajemen dipandang sebagai suatu bidang pengetahuan yang secara sistemik berusaha memahami mengapa dan bagaimana orang bekerjasana. Dikatakan kiat karena manajemen mencapai sasaran melalui cara-cara dengan mengatur orang lain menjalankan tugas. Dipandang sebagai profesi karena manajemen dilandasi oleh keahlian khusus untuk mencapai suatu profesi, manajer dan para professional dituntut oleh kode etik. (Nanang Fattah, 2009:1)

Standar Pembiayaan Satuan Pendidika diatur dalam Peraturan Menteri Nasional Pendidikan Nomor 69 Tahun 2009 tentang Standar Biaya Operasional dan Nonpersonalia Tahun 2009 untuk SD/MI/SDLB, SMP/MTs/SMPLB, SMA/MA/SMALB, dan SMK, yang mencakup: Ketentuan jumlah rombel per sekolah/program keahlian dan jumlah peserta didik per rombel untuk perhitungan biaya operasi nonpersonalia.

Biaya pendidikan menurut sumbernya tergolong atas biaya yang dikeluarkan oleh pemerintah baik pusat maupun daerah, biaya yang dikeluarkan oleh masyarakat orang tua/wali siswa, dan lembaga pendidikan itu sendiri. (Harsono, 2007:10)

Biaya Langsung terdiri dari biaya-biaya yang dikeluarkan untuk keperluan pelaksanaan pengajaran dan kegiatan belajar mengajar siswa, berupa pembelian alat-alat pelajaran, sarana belajar, biaya transportasi, gaji guru, baik yang dikeluarkan oleh pemerintah, orang tua, maupun siswa. (Nanang Fattah, 2004:23) 
Standar Penilaian Pendidikan, diatur melalui Peraturan Menteri Nasional Pendidikan Nomor 20 Tahun 2007 Tanggal 11 Juni 2007, yang mencakup: Pengertian, Prinsip, Teknik dan Instrumen, Mekanisme dan prosedur penilaian, Penilaian pendidik, Penilaian oleh Satuan Pendidikan dan Pemerintah.

Penilaian adalah keputusan tentang nilai. Oleh karena itu, langkah selanjutnya setelah melaksanakan pengukuran adalah penilaian. Penilaian dilakukan setelah siswa menjawab soal-soal yang terdapat tes. Hasil jawaban siswa tersebut ditafsirkan dalam bentuk nilai. (Calongesi, James S, 1995:21)

Evaluasi lebih luas artinya dan lebih komprehensif dari pada pengukuran maupun assessment. Evaluasi hasil belajar merupakan assessment peserta didik dalam mengungkapkan proses belajar peserta didik secara menyeluruh. (Suharsimi Ari Kunto, 2009:3)

Penelitian ini akan mengungkap kondisi real standar nasional pendidikan (SNP) berdasarkan delapan aspek/ komponen dan diakumulasi untuk mengetahui tingkat kualitas madrasah aliyah berdasarkan kategori. Adapun aspek yang dijaring di madrasah, sebagai berikut: 1) Kurikulum (mengembangkan perangkat pembelajaran pada kompetensi sikap, spritual, sosial, keterampilan ruang lingkup pembelajaran; mengembangkan kurikulum sesuai pedoman dan prosedur operasional serta pelaksanaan silabus dan RPP); 2) Proses (mengalokasikan waktu dan beban belajar, serta pengelolaan kelas); 3) Lulusan (mencerminkan sikap pembelajaran dan sehat jasmani/rohani; keterampilan berfikir dan bertindak; siswa per rombel, penggunaan buku teks dan pelaksanaan pengawasan); 4)Pendidik/ Kependidikan (tingkat kualifikasi guru/staf dan sertifikasi); 5) Sarpras (lahan, bangunan, kelengkapan sarana dan pemeliharaan; 6) Pengelolaan (Visi dan misi, RKJM/RKT, pedoman dan sistem informasi manajemen); 7) Pembiayaan (rencana kerja anggra, biaya operasional, sumbangan, pembukuan dan pelaporan keuangan); 8) Evaluasi (kriteria KKM, penilaian hasil belajar dan ketentuan kelulusan siswa).

\section{Metode Penelitian}

Jenis penelitian adalah penelitian survei yang akan mengungkap kondisi real madrasah aliyah dengan menggunakan teori edukasi yang relevan pada obyek penelitian. Sasaran penelitian adalah MAS di Kabupaten Kolaka dengan menggunakan metode kuantitatif. Adapun sumber data adalah Kementerian Agama Propinsi Sulawesi Tenggara, Kementerian Agama Kabupaten Kolaka, Komponen Madrasah Aliyah, dan BPS. Sedangkan Instrumen penelitian berupa angket, wawancara, dan observasi.

\section{HASIL DAN PEMBAHASAN Kondisi Madrasah}

Secara keseluruhan jumlah madrasah swastayang tersebar di Kabupaten Kolaka terdapat 45 yaitu, sebagai berikut: MIS 14, MTs 22, dan MAS 9. Sedangkan jumlah guru madrasah 135 dan siswa 636. lebih 
jelasnya dapat dilihat pada tabel, sebagai berikut:

\section{Tabel 1. Jumlah MA berdasarkan Guru dan Siswa}

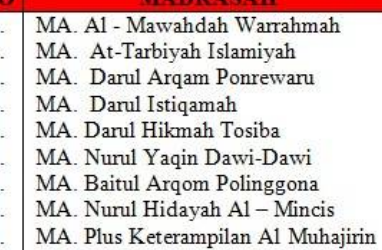

\begin{tabular}{|c|c|}
\hline 24 & 145 \\
15 & 49 \\
15 & 117 \\
11 & 27 \\
12 & 43 \\
16 & 140 \\
21 & 185 \\
10 & 21 \\
11 & 9 \\
\hline 135 & 636 \\
\hline
\end{tabular}

Sumber Data KementerianAgama Kab. Kolaka

Keberadaan MAS yang tersebar pada tujuh wilayah Kecamatan di Kabupaten Kolaka, yang memiliki khas tersendiri. Dimana madrasah aliyah sebagian besar di bawah naungan yayasan dan pondok pesantren. Salah satu madrasah aliyah yang telah memiliki Rumah Tahfiz dan telah merekrut santri 80 orang tahun 2017 adalah MAS Nurul Yaqin Dawi-Dawi. Sedangkan tahun berdiri dan operasional madrasah antara 1991 2002.

Secara kuantitas kondisi siswa dan tenaga pendidik dan kependidikan pada madrasah aliyah swasta belum signifikan, begitupun halnya dengan minat serta kepedulian masyarakat terhadap madrasah masih rendah. Para guru MAS memiliki keterbatasan dalam meningkatkan SDM. Sehingga, kegiatan pengembangan dalam meningkatkan sumber daya manusia dominan hanya sosialisasi dibanding kegiatan pendidikan dan pelatihan (diklat).

\section{Kualitas MAS}
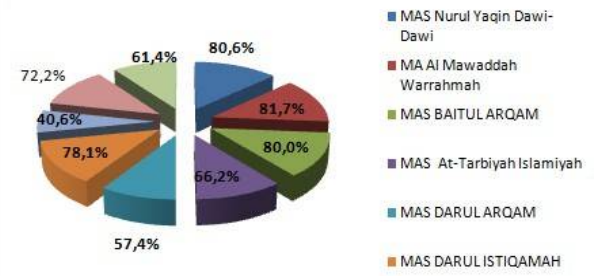

I MAS DARULISTIQAMAH
Berdasarkan grafik di atas, secara generalisasi menunjukkan bahwa adanya variasi tingkat capaian pada aspek standar nasional pendidikan (SNP). Adapun yang dimaksud bervariasi, yaitu: Standar Kurikulum, Lulusan, Proses, Tenaga Pendidik dan Kependidikan, Sarana dan Prasarana, Pengelolaan, Pembiayaan, dan Penilaian.

Secara kuantitas dan kualitas dalam pengembangan madrasah masih memerlukan dukungan dari masyarakat dan pemerintah, terutama pada aspek sarana dan prasarana, tenaga pendidik dan kependidikan, dan ciri khas madrasah. Komponen inilah yang menjadi urgen di setiap madrasah, sehingga belum bisa mewujudkan harapan masyarakat secara signifikan dalam proses belajar mengajar (PBM).

Lebih jelasnya akan diuraikan secara rinci pada tabel, berdasarkan tingkat capaian SNP pada MAS di Kabupaten Kolaka, sebagai berikut:

\section{CIRI KHAS}

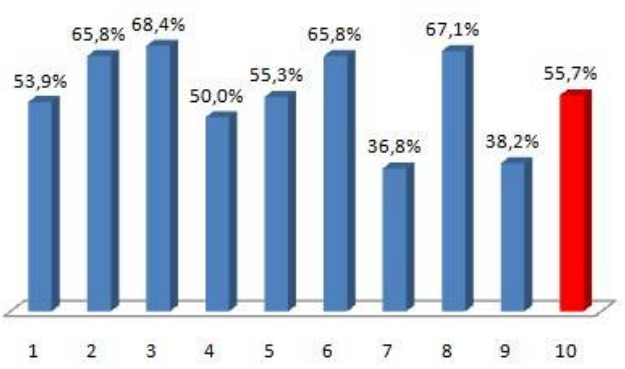

\section{Kualitas Standar}

Indikator tingkat capaian "ciri khas" merupakan konsep peneliti bidang pendidikan agama dan keagamaan Litbang Agama Makasssar. Dimana, standar tersebut dapat dijadikan sebagai salah satu bahan penilaian pada lembaga pendidikan agama (madrasah). Ada 
beberapa indikator yang dilihat pada komponen ciri khas, yaitu: Pengembangan Mata pelajaran Agama, Ekstrakurikuler keagamaan, Penciptaan suasana keagamaan, dan pendalaman dan pengamalan ajaran agama.

Pada umumnya madrasah telah mengajarkan lima mata pelajaran pendidikan agama, di antaranya: Quran Hadits, Fiqh, Aqidah Akhlak, SKI, dan Bahasa Arab. Ini merupakan landasan wajib yang harus diajarakan, karena termaktub dalam kurikulum 13. Namun, dalam implementasi pengembangan pembelajaran ekstrakurikuler keagamaan belum teraplikasi secara signifikan, karena adanya batasan yang dimiliki madrasah, diantaranya: fasilitas pembelajaran, waktu dan SDM pengelola (guru).

Indikator

ekstrakurikuler keagamaan yang dijadikan sebagai penilaian adalah: a) Peningkatan pendalaman Aqidah (pengajian jumat sore, shalat dhuha setiap pagi, tadarrus setelah shalat dhuha, dan zikir asmaul husnah); b) Peningkatan kemakhiran dan pemahaman Alqur'an Hadits (TPQ); c) Peningkatan pengamalan ibadah (safari ramadhan); d) Peningkatan Akhlak (kultum dari guru setiap pagi dan kultum dari siswa setelah shalat dhuhur); e) Peningkatan kemampuan berbahasa Arab (latihan ceramah bahasa Arab); dan f) Peningkatan pengetahuan terhadap sejarah kebudayaan Islam.

Implementasi PBM pada kegiatan ekstrakurikuler keagamaan, dominan madrasah memfokuskan pada "peningkatan dan pendalaman aqidah akhlak". Walaupun masih terdapat dua madrasah (MAS Darul
Hikmah dan MAS Plus Keterampilan Al-Muhajirin) yang belum mengembangkan kegiatan. Namun, dari akumulasi tidak mengurangi tingkat capaian pada ciri khas madrasah dengan kategori "Tinggi".

\section{KURIKULUM}

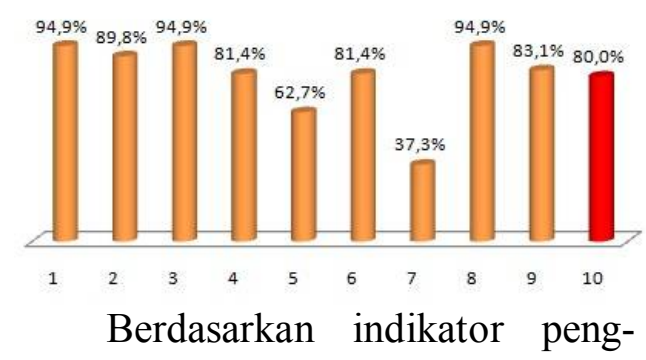

embangan kurikulum tentang implementasinya, masih memerlukan bimbingan dan pembinaan bagi guru madrasah, khususnya MAS Darul Hikmah. Adapun indikitaor pada komponen kurikulum, yaitu: Pengembangan kompetensi siswa, Pelibatan pada kegiatan pengembangan kurikulum, Kegiatan penyusunan kurikulum, Prosedur pengembangan kurikulum, Pelaksanaan kurikulum, Pengembangan silabus, dan Pengembangan RPP.

Substansi kurikulum 13 mengemas kompetensi sosial dan religius, dalam operasionalnya memerlukan dukungan perangkat/ media pembelajaran. Sehingga, pelaksanaan dapat diaplikasikan berdasarkan ketentuan atau aturan dalam penerapan K13. Ada beberapa kendala dalam implementasinya yaitu: a) kurang sosialisasi; b) mengkolaborasi kurikulum (pesantren dan madrasah); c) terbatasnya SDM pengelola dan anggaran.

Regulasi penganggaran K13 hanya pada madrasah negeri (induk) saja, sehingga dibutuhkan inovasi dan kreatifitas madrasah swasta dalam memenuhi pengembangan 
perangkat pembelajaran sesuai dengan tingkat kompetensi dan ruang lingkup materi pembelajaran pada setiap tingkat kelas. Namun, akumulasi pengembangan kurikulum madrasah terkategori "Sangat Tinggi".

\section{LULUSAN}

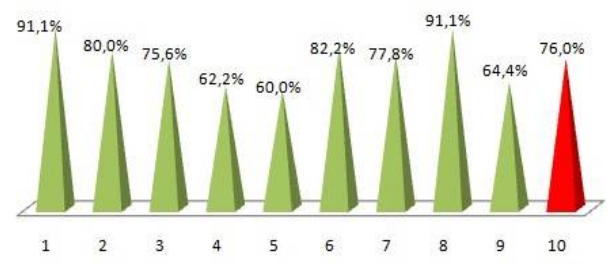

Beberapa indikator penilaian pada komponen kelulusan (perilaku dan sikap siswa), yaitu: dengan melihat Sikap Taqwa, Sosial, Belajar, Hidup sehat, Berfikir, dan Keterampilan Ilmiah dan Bertindak.

Madrasah dikatakan bermutu, apabila mampu menghasilkan suatu lulusan yang bisa memenuhi empat kompetensi, diantaranya: kompetensi nilai dan sikap. Tingkat capaian madrasah pada standar kelulusan terkategori "Sangat Tinggi". Walaupun masih terdapat beberapa indikator, yang masih memerlukan peningkatan guna mencerminkan sikap pembelajaran sejati melalui gerakan literasi madrasah dan keterampilan berfikir siswa secara kreatif, produktif dan kritis melalui pendekatan ilmiah sebagai pengembangan diri.

Dari tujuh indikator sikap belajar, belum semua dapat di implementasikan pihak madrasah. Adapun gerakan literasi yang dilaksanakan, adalah: membaca buku, memajang karya tulis dan lomba terkait literasi. Sedangkan yang terkait dengan berpikir secara kreatif, produktif dan kritis adalah: studi wisata belum dapat diimplementasikan, karena memerlukan biaya operasional yang tidak sedikit serta kegiatan seminar dan workshop.

\section{PROSES PENDIDIKAN}

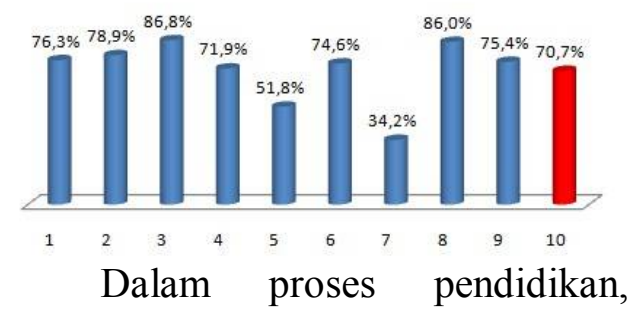
terdapat sembilan indikator (waktu belajar, Jumlah rombel dan penggunaan buku, pengelolaan kelas, proses pembelajaran, pengawasan dan supervisi, pemantauan proses pembelajaran, tindak lanjut hasil supervisi, laporan pengawasan, supervisi, dan pemantauan, serta pelaksanaan hasil tindak lanjut) yang dijadikan sebagai rujukan guna meningkatkan kualitas terutama pada pengalokasian waktu pembelajaran. Karena durasi pembelajaran dan beban belajar merupakan suatu pedoman untuk dapat mengukur tingkat pencapaian PBM dan pelaksanaan ujian semester.

Pemantauan

proses pembelajaran salah satu cara untuk bisa meningkatakan output dari berbagai aspek pendidikan. Kepala madrasah memiliki wewenang dalam hal pemantauan. Adapun yang dijadikan sebagai bahan pemantauan, sebagai berikut: Diskusi kelompok terfokus, pengamatan, pencatatan, perekaman, wawancara, dan pendokumentasian. Sebagian besar madrasah hanya mengimplementasikan pemantauan pada aspek pengamatan dan pencatatan saja. Pemantauan dilaksanakan, agar bisa mengetahui secara pasti metode dan 
cara mengajar serta menjadikan pedoman penilaian terhadap guru.

Sedangkan menidaklanjuti
hasil supervisi dengan cara pemberian contoh, diskusi, konsultasi dan pelatihan. Hanya konsultasi dan pelatihan yang belum semua diimplementasikan kepala madarsah. Namun, secara keseluruhan menunjukkan tingkat capaian madrasah dengan melihat sembilan indikator pada proses pendidikan terkategori "Tinggi".

\section{PENDIDIK DAN KEPENDIDIKAN}

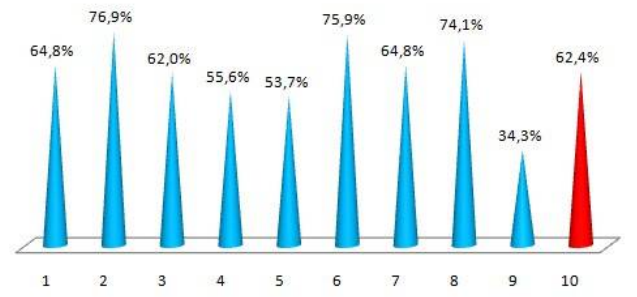

Indikator pada komponen pendidik dan kependidikan adalah Kualifikasi dan sertifikasi, Kompetensi, persyaratan Kepala Madrasah, Kompetensi manajerial, kewirausahaan, dan supervisi Kamad, Tenaga kependidikan dan tenaga khusus.

$\begin{array}{llr}\text { Tenaga } & \text { kependidikan adalah } \\ \text { anggota } & \text { masyarakat yang }\end{array}$ mengabdikan diri dan diangkat untuk menunjang penyelenggaraan pendidikan. (Suharno, 2008:14). Sedangkan Tenaga kependidikan nonguru adalah anggota masyarakat yang mengabdikan diri dan di angkat untuk menunjang penyelenggaraan pendidikan non-formal dan informal.

Kualifikasi tenaga pendidik rata-rata sarjana dan memiliki sertifikan pendidik dan kompetensi. Begitupun halnya dengan para kepala madrasah memiliki kompetensi manajerial. Walaupun masih terdapat beberapa madrasah yang yang masih mengampuh mata pelajaran sampai 4 bidang studi dan memiliki latar belakang pendidikan umum.

Sedangkan tenaga administrasi (kependidikan) madrasah rata-rata berpendidikan $\mathrm{S} 1$ dengan pengalaman 4 tahun dan Diploma berpengalaman $5-8$ tahun. Secara kuantitas tenaga adminsitrasi sangat minim, sehingga sistem yang diterapkan dengan cara kolaborasi (saling membantu) sesama guru. Bahkan terdapat beberapa madrasah, kegiatan administrasinya ditangani langsung oleh pihak yayasan.

Petugas khusus madrasah, di antaranya: penjaga madrasah, tukang kebun, tenaga kebersihan, pesuruh, dan pengemudi. Secara keseluruhan belum dapat terpenuhi, karena adanya batasan yang dimiliki seperti: anggaran dan kondisi lingkungan. Sehingga, pihak madrasah/yayasan hanya memiliki petugas yang akan melaksanakan layanan khusus secara rangkap (penjaga dan tenaga kebersihan) saja.

Adapun tingkat capaian madrasah pada kompetensi tenaga pendidik dan kependidikan terkateori "Tinggi". Ini disebabkan oleh strategi dan kebijakan yang diterapkan oleh kepala madrasah dan yayasan dalam mengimplementasi PBM dan mengelola kegiatan administrasi.

\section{SARANA DAN PRASARANA}

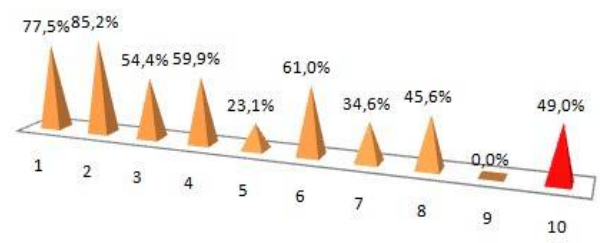

Berdasarkan dari beberapa hasil penelitian Litbang Agama (peneliti pendidikan) tentang 
"Kualitas Madrasah", standar sarana dan prasarana yang sangat urgen dalam hal pemenuhan. Sehingga pihak madrasah dalam mengimplementasikan proses belajar mengajar mengkondisikan fasilitas/media sesuai kebutuhan. Pada umumnya pihak lembaga pendidikan lebih mengutamakan pengadaan ruang pembelajaran dibanding ruang laboratorium, perpustakaan, apalagi ruang OSIS dan lahan parkir.

Indikator Sarpras, yaitu: lahan dan bangunan, beberapa ruang, tempat olahraga, jamban, gudang, kantin, dan tempat parkir. Kepemilikan bangunan madrasah memenuhi persyaratan kesehatan dan keselamatan, walaupun sebagian belum memiliki ruang laboratorium. Pengadaan fasilitas PBM tidak terlepas dari bantuan pemerintah, yaitu: dana BOS, tetapi pengadaan fasilitas pada kegiatan ekstrakurikuler dominan pihak madrasah berupaya secara mandiri, salah satu contoh: MAS Nurul Yaqin dawi-dawi pemenuhan fasilitas pada kegiatan pengembangan diri siswa, lebih mengutamakan usaha sendiri. Strategi yang ditempuh adalah sering mengikuti/menampilkan ikon madrasah baik tingkat lokal sampai nasional, ini merupakan sosialisasi dan promosi. Pada prinsipnya "bagaimana bisa dikenal kalau tidak pernah memperlihatkan hasil". Hal ini merupakan modal dalam memajukan atau mengembangkan madrasah ke depan.

Dalam tingkat capaian kompetensi sarana dan prasarana madrasah secara keseluruhan terkategori "Rendah". Walaupun dalam hal bangunan telah memenuhi persyaratan keselamatan dan kesehatan, tetapi fasilitas masih sangat minim dalam mengembangkan PBM.

\section{PENGELOLAAN PENDIDIKAN}

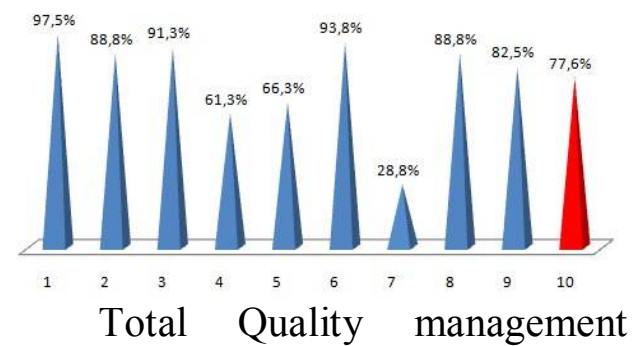
(TQM) adalah suatu pendekatan manajemen untuk suatu organisasi yang terpusat pada kualitas, berdasarkan partisipasi semua anggotanya dan bertujuan untuk kesuksesan jangka panjang melalui kepuasan pelanggan serta memberi keuntungan untuk semua anggota dalam organisasi serta masyarakat. (Gaspersz Vincent, 2001:22).

Pedoman pengelolaan yang di miliki madrasah sangat bervariatif, baik pengembangan kurikulum, pembagian tugas guru dan tenaga kependidikan, peraturan akademik, maupun biaya operasional. Strategi dan kebijakan merupakan hal terpenting yang harus dimiliki pihak pengelola terutama para kepala madrasah, dalam mengembangkan suatu lembaga pendidikan (madrasah).

Madrasah telah melaksanakan pengelolaan bidang kurikulum dan kegiatan pembelajaran yang meliputi kurikulum, kalender, program, penilaian, dan peraturan akademik. Namun, dalam menyusun pedoman pengelolaan pembiayaan investasi dan operasional, sebagian besar madrasah hanya mengatur tentang sumber pemasukan, pengeluaran, dan jumlah dana. Sedangkan penyusunan dan pencairan anggaran, mengatur 
tentang pembukuan serta mengatur tentang kewenangan dan tanggung jawab madrasah dalam membelanjakan anggaran, sepenuhnya adalah wewenang yayasan.

Madrasah telah melibatkan masyarakat dan membangun kemitraan dengan lembaga lain yang relevan dalam melakukan berbagai kegiatan pengelolaan pendidikan, diantaranya: lembaga pendidikan, keagamaan dan kemasyarakatan, dunia usaha, dan pengembangan minat dan bakat. Sedangkan pelaksanaan kegiatan evaluasi diri terhadap kinerja madrasah dalam rangka pemenuhan Standar nasional Pendidikan (SNP) melaksanakan sekali dalam 1-3 tahun.

Kepala madrasah telah menerapkan prinsip-prinsip kepemimpinan pembelajaran dalam mengelola madrasah, yang meliputi: membangun tujuan bersama, meningkatkan kreasi dan inovasi daklam pengembangan kurikulum, mengembangan motivasi guru, menjamin pelaksanaan mutu proses pembelajaran, mengembangkan sistem penilaian, dan mengambil keputusan berbasis data. Sehingga yang dominan diaplikasikan pihak madrasah adalah aspek Mengembangkan motivasi guru, mengembangkan sistem penilaian, dan mengembangakan tujuan bersama.

Secara keseluruhan menunjukkan tingkat capaian madrasah terhadap komponen pengelolaan pendidikan terkategori "Sangat Tinggi”.

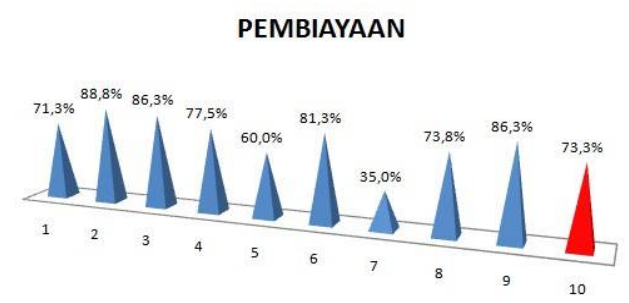

Rencana kerja anggaran (RKA) madrasah memuat alokasi anggaran untuk investasi, biaya operasi nonpersonalia, dokumen sarana dan prasarana, biaya operasional guru dan tenaga kependidikan, pemanfaatan anggaran, dan memiliki pembukuan dan laporan keuangan.

RKA pada alokasi anggaran untuk investasi, diperuntukkan pada pengembangan sarana dan prasarana, pendidikan dan kependidikan. Dimana terdapat lima sekolah yang belum mengalokasikan anggaran untuk investasi modal usaha. Sedangkan untuk biaya operasi nonpersonalia, hanya tiga madrasah yang mengalokasikan untuk asuransi dan dua madrasah yang belum memiliki dokumen investasi sarana dan prasarana. Begitupun halnya pada biaya operasional guru dan staf hanya diperuntukkan pada gaji, honorer kegiatan, dan intensif, kalau untuk tunjangan lain hanya lima madrasah yang telah mengalokasikan.

Rata-rata madarsah merealisasikan anggaran 91\%-100\%, dalam bentuk pembiayaan pengembangan pendidik dan kependidikan, ATK, pemeliharaan, perjalanan dinas, pembinaan siswa. Sedangkan pemanfaatan sumbangan pendidikan dari masyarakat dikelola secara transparan, sistimatis, efesien dan akuntabel, dengan memiliki pembukuan (buku bantu kas, buku kas umum, buku bantu bank, dan 
tidak semua madrasah memiliki buku bantu pajak. Pelaporan/ pertanggungjawaban keuangan madrasah dominan melaporkan kepada pemberi sumbangan/bantuan, yaitu: Pemerintah dan orang tua selama 3 tahun terakhir.

Pemahaman madrasah terhadap pengalokasian anggaran telah diaplikasikan secara profesional berdasarkan juknis, sehingga tingkat capaian komponen pembiayaan terkategori "Tinggi".

\section{PENILAIAN}

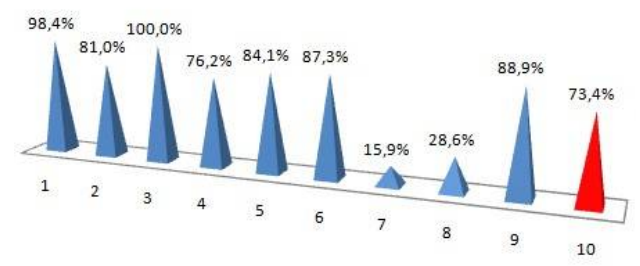

Penentuan kriteria ketuntasan minimal (KKM) pada seluruh mata pelajaran telah mempertimbangkan beberapa karakteristik, yaitu: Peserta didik, mata pelajaran, kondisi satuan pendidikan, dan analisis hasil penilaian. Tujuan KKM adalah untuk memperoleh hasil akhir yang valid dan akurat serta merupakan ketentuan dari kurikulum. Sehingga harus diterapkan atau dilaksanakan madrasah.

Kriteria Ketuntasan Minimal (KKM) telah diimplemetasikan 91\%$100 \%$ berdasarkan ketentuan. Adapun cara guru melaksanakan penilaian hasil belajar siswa berdasarkan 6 prinsip penilaian, yaitu: sahih, objektif, adil, terbuka, holistik, dan akuntabel. Sedangkan bentuk penilaiannya berdasarkan ulangan, pengamatan, penugasan, dan bentuk lain. Adapun jenis penilaian, yaitu: Kompetensi sikap, pengetahuan, keterampilan yang sesuai dengan karakteristik
Kompetensi Dasar (KD). Begitupun dengan kriteria penilaian hasil belajar diaplikasikan dalam bentuk penilaian harian, akhir semester, akhir tahun, dan ujian madrasah.

Terkait dengan tingkat capaian madrasah terhadap komponen penilaian, terdapat dua madrasah yang masih memerlukan bimbingan dan pembinaan dalam mengimplementasikan penilaian berdasarkan kriteria ketuntasan minimal (KKM). Namun, secara keseluruhan tingkat capaian madrasah pada komponen penilaian pendidikan terkategori "Tinggi".

Berdasarkan uraian di atas, tentang kondisi tingkat capaian Standar Nasional Pendidikan (SNP) dengan melihat beberapa indikator pada standar/kompetensi sangar bervariatif, khususnya pada MAS dalam mengembangkan madrasah. Pengelola madrasah swasta masih memerlukan pembinaan dan bimbingan berkesinambungan, agar dapat meningkatkan kualitas dari berbagai aspek. Sehingga, madrasah mampu memberikan kontribusi pelayanan dan kenyamanan dalam kegiatan PBM, serta dapat bersaing dengan lembaga pendidikan lainnya.

Lebih jelasnya dapat dilihat pada tabel rekapitulasi tingkat ketercapaian standar nasional pendidikan (SNP) madrasah berdasarkan standar/kompetensi yang telah diaplikasikan MAN/MAS Kabupaten Kolaka, sebagai berikut:

$$
\text { TINGKAT KUALITAS MAS }
$$

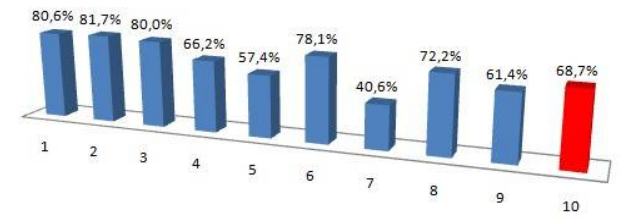


Keterangan:

1. Sangat Tinggi (ST) : $76 \%-100 \%$

2. Tinggi (T) $: 51 \%-75 \%$

3. Rendah (R) : $: 26 \%-50 \%$

4. Sangat Rendah (SR): $0 \%-25 \%$

Ketercapaian standar nasional pendidikan (SNP) MAS di Kabupaten Kolaka dengan melihat berbagai indikator pada komponen, masih terdapat beberapa yang perlu dikembangkan atau ditingkatkan. Diantaranya: pada aspek ciri khas, tenaga pendidik dan kependidikan serta sarana dan prasarana. Walaupun ketercapaian secara keseluruhan menunjukkan "Tinggi". Tetapi pembimbingan dan pembinaan masih sangat diperlukan pihak madrasah, agar bisa mengaplikasikan PBM secara efektif dan efesien.

Salah satu indikator ciri khas yang perlu dikembangkan yaitu: pemberian tambahan materi agama yang relevan pada mata pelajaran umum (belum semua pengelola (guru) mata pelajaran umum dapat mengaplikasikan secara rutin mata pelajaran dikaitkan dengan nilai-nilai spritual keagamaan dalam pembelajaran).

Adapun keterbatasan yang dimiliki madrasah, yaitu: karena latar belakang pendidikan guru dominan Sarjana Umum dan masih mengampu beberapa mata pelajaran. Sehingga penambahan materi pelajaran agama merupakan inisiatif pengelola (guru) masing-masing.

Begitupun pada peningkatan pada kegiatan ekstrakurikuler, terutama pada aspek peningkatan dan pendalaman aqidah akhlak, kemakhiran dan pemahaman terhadap Alquran dan hadits, pengamalan ibadah, pengetahuan
SKI dan kemampuan berbahasa arab. Karena program ini memerlukan dukungan yang kuat, terutama fasilitas kegiatan dan tenaga pengelola (guru).

\section{PENUTUP}

\section{Kesimpulan}

Berdasarkan hasil temuan yang telah diurai di atas, dengan melihat beberapa indikator pada komponen standar nasional pendidikan (SNP) masih terdapat beberapa standar yang memerlukan pembenahan dalam meningkatkan kualitas madrasah.

Ada beberapa aspek, di antaranya: dukungan fasilitas dan media pembelajaran pada kegiatan ekstrakurikuler belum efektif, Minimnya keterlibatan guru/ pengelola madrasah swasta mengikuti kegiatan pengembangan diri (diklat), Manajemen madrasah masih dominan dikelola oleh yayasan, serta kurangnya penguatan/ sosialisasi madrasah terhadap orang tua dalam pengembangan madrasah. Dan yang tak kalah pentingnya adalah pengrekrutan dan penempatan tenaga pendidik dan kependidikan belum berjalan secara selektif.

Madrasah belum memiliki konsep kemandirian yang bisa dijadikan sebagai pedoman/rujukan dalam meningkatkan dan mengembangkan madrasah. Sementara, masih terfokus pada proses belajar mengajar dan pemenuhan ketuntasan kriteria minimal yang berdasar pada kurikulum dan silabus.

\section{Rekomendasi}

Inovasi dan kreatifitas merupakan salah satu konsep, yang 
harus dimiliki pengelola (guru) dalam mengembangkan suatu lembaga pendidikan. Pemenuhan operasional pembelajaran dapat terealisasi, apabila pihak madrasah mampu mengkolaborasikan kebutuhan dan program bersama masyarakat.

Pendidikan dan latihan (diklat) merupakan jalur peningkatan SDM guru, maka diharapkan pemerintah bisa selektif dalam melibatkan pengelola madrasah. Begitupun pada perekrutan dan penempatan dilaksanakan atas dasar kebutuhan, serta diperlukan adanya kejelasan tanggungjawab dan tupoksi antara pihak yayasan dengan pengelola.

Perwujudan

dalam mengembangkan/membangun suatu lembaga pendidikan madrasah, diperlukan adanya penguatan sinergisitas dari berbagai elemen, di antaranya: masyarakat dan pemerintah (Pemda, Kemendiknas dan Kemenag).

\section{DAFTARA PUSTAKA}

Barnawi \& M. Arifin. 2012. Manajemen Sarana Dan Prasarana Sekolah. Yogyakarta, Ar- Ruzz Media

Calongesi, James S. 1995.

Merancang Tes Untuk Menilai Prestasi Siswa. Bandung, Institut Teknologi Bandung (ITB)

Mulyasa, E. 2005. Menjadi Guru Professional. Bandung. Remaja Rosdakarya.
Gapersz Vicent, 2001. Total Quality

Management.

Jakarta.

Gramedia Pustaka Utama.

Hasbullah. 2007. Otonomi Pendidikan. Jakarta, Raja Grafindo Persada

Harsono. 2007. Pengelolaan Pembiayaan Pendidikan. Yogyakarta, Pustaka Book Publisher.

M. Dachlan Al Barry. 1994. Kamus Modern Bahasa Indonesia, Arloka. Yogyakarta.

Nanang Fatah. 2009. Landasan Manajemen Pendidikan. Bandung, Remaja Rosdakarya.

Peraturan Menteri Pendidikan Nasional Nomor 22 Tahun 2006 Tanggal 23 Mei 2006, tentang Standar Isi

Peraturan Menteri Pendidikan Nasional Nomor 41 Tahun 2007 Tanggal 23 November 2007, tentang Standar Proses.

Peraturan Menteri Pendidikan Nasional Nomor 23 Tahun 2006 Tanggal 23 Mei 2006, tentang Standar Kompetensi Lulusan.
Peraturan Menteri Pendidikan Nasional Nomor 16 Tahun 2007 tentang Standar Kualifikasi Akademik dan Kompetensi Guru.

Peraturan Menteri Pendidikan Nasional Nomor 24 Tahun 2007 Tanggal 28 Juni 2007, tentang Standar Sarana Dan Prasarana

Peraturan Menteri Pendidikan Nasional Nomor 19 Tahun 2007 Tanggal 23 Mei 2007, 
tentang Standar Pengelolaan Pendidikan

Peraturan Menteri Pendidikan Nasional Nomor 69 Tahun 2009 tentang Standar Biaya Operasional Nonpersonalia

Peraturan Menteri Pendidikan Nasional Nomor 20 Tahun 2007 Tanggal 11 Juni 2007, tentang Standar Penilaian Pendidikan

Piet A. Sihertian. 1994. Dimensi Administrasi Pendidikan. Surabaya, Usaha Nasional

Quraish Shihab. 1999. Membumikan Al-Qur'an. Mizan, Bandung

Suharsimi Ari Kunto. 2009, Dasardasar Evaluasi Pendidikan. Jakarta, Bumi Aksara.

Suharno 2008, Manajemen Pendidikan (Pengantar Bagi Para Calon Guru), Cet. II (Surakarta LPP UNS Press).

Supriyanto, A. 1997. Jurnal Ilmu Pendidikan Mutu Pendidikan Sekolah Dasar di Daerah Diseminasi, Jilid 4, IKIP.

Syafaruddin \& Irwan Nasution. $2005 . \quad$ Manajemen Pembelajaran. Jakarta. Quantum Teaching.

Trianto dan Titik Triwulan. 2006. Tinjauan Yuridis Hak Serta Kewajiban Pendidik (menurut UU Guru dan Dosen), Jakarta. Prestasi Pustaka.

Undang-Undang Republik Indonesia Nomor 14 Tahun 2005 pasal 1 (1), tentang Guru Dan Dosen. Bandung 2006. Citra Umbara.
Undang-Undang No. 20 tahun 2003

Tentang Sistem Pendidikan

Nasional, Pasal 1, ayat (5). 